\title{
Ihminen murroksessa
}

\section{Georg Henrik von Wright 1996. Ihminen kulttuurin murroksessa. Otava.}

Georg Henrik von Wrightin teoksessa Ihminen kulttuurin murroksessa ehkä kiehtovin essee on vuonna 1994 kirjoitettu Berdjajev. Von Wright pitää Nikolai Berdjajevia merkittävimpänä vallankumouksen jälkeen eläneenä venäläisenä filosofina. Berdjajevia arvostettiin uskonnon- ja historianfilosofina ja hän keskittyi ennen kaikkea tekniikan kehityksen aiheuttamiin yhteiskuntafilosofisiin ongelmiin. Hän piti koneen ja ihmisen suhdetta "teknosysteeniinä", joka ei kuulunut epäorgaaniseen maailmaan, vaan toimi organismin tavoin. Tätä suhdetta hän luonnehti Put -lehdessä vuonna 1932 seuraavasti:

"Ei ole liioiteltua välttää että tekniikasta on tullut kulttuurin ja koko ihmiskunnan kohtalonkysymys. Meidän uskonnottomana aikanamme, kun uskonnon lisäksi myös varhaisempien vuosisatojen humanistinen usko on heikentynyt, on nykyajan sivilisoituneella ihmisellä jäljellä yksi ainoa usko, usko tekniikkaan, sen valtaan ja rajattomiin kehitysmahdollisuuksiin."

Organismin korvaa Organisaatio. Aiemmin orgaanisena koettu luonto, Äiti maa, kuvataan keinotuotteena, artefaktina, josta Puhutaan teknisin metaforin. Tässä teknosysteemissä ihminen kasvaa yhteen koneen kanssa ja uudessa symbioosissa hänestä tulee kosmiurgi, maailman luoja, joka lisää kahdeksannen päivän Luojan luomistyöhön.

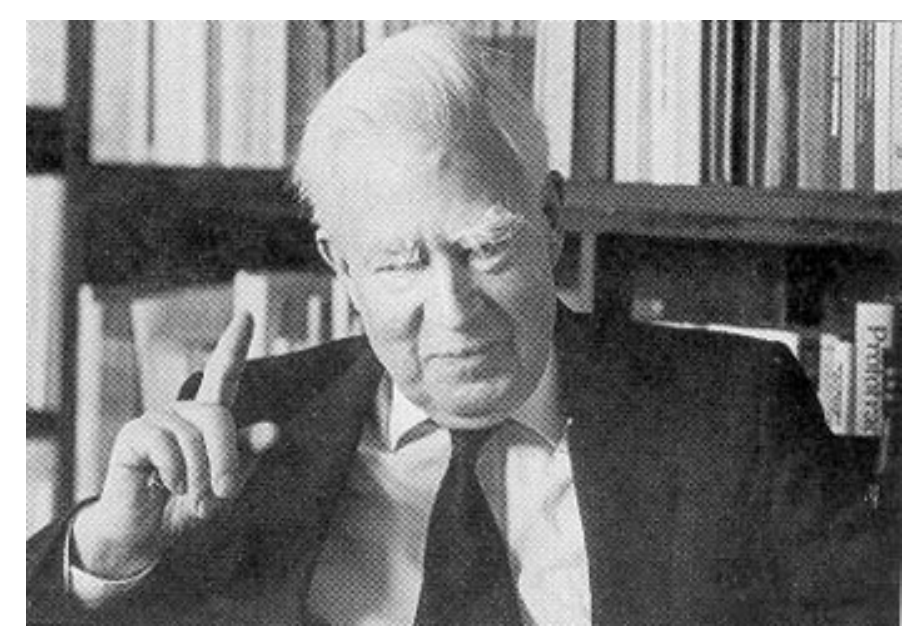

Georg Henrik von Wright täyttää14. kesäkuuta 80 vuotta.
Georg Henrik von Wright tuo esiin sen, että maailmankuvan pirstaloituminen on tieteellisen rationaalisuuden oman sisäisen kehityksen vääjäämätön seuraus. Maailmankuvan hajotessa todellisuus näyttäytyy absurdina ja irrationaalisena. Tästä Berdjajev toteaa:

"Ajallemme on ominainen irrationaalisuuden ja rationaalisuuden liitto. Tämä voi vaikuttaa ristiriitaiselta mutta on itse asiassa aivan ymmärrettävää. Irrationaaliset voimat murtautuvat äkkiä esiin ja avautuva kaaos nielaisee ihmisen. Hän yrittää kouristuksenomaisesti pelastautua lisäämällä elämänsä rationalisointia. Tämä prosessi on kuitenkin vain rationaalisuuden kasvamisen toinen puoli. Ihmisen ja maailman tilanne koetaan absurdiksi, mielettömäksi. "

Ratkaisuksi ihmisen eksistenssihätään Berdjajev tai von Wright eivät kuitenkaan esitä valheellista romanttista unelmaa paluusta esiteolliselle ja esiteknologiselle tasolle. Paratiisiin ei ole paluuta sen enempää teknisten apuvälineiden hylkäämisellä kuin kehityksen kieltämiselläkään. Ainoa keino on oppia säätelemään kehitystä ja etsiä tasapainoa fyysisen ympäristön ja henkisen todellisuutemme välillä.

Teoksessa Ihminen kulttuurin murroksessa on laaja kaari von Wrightin esseitä eri ajoilta. Essee Dostojevski on ilmestynyt aikaisemmin vuonna 1949, Spengler ja Tbynbee vuonna 1951 ja Tolstoi ajattelijana vuosina 1952-1954. Nämä kolme esseetä luovat teoksen selkärangan ja jännitteen, johon uusi ,oman vuosikymmenemme, näkökulma syntyy kolmesta uudesta esseestä. Vuonna 1994 kirjoitettu Mietteitä hämärän aikaan luo linjaa ja selittää näiden esseiden lähtökohtia ja yhtymäkohtia. Vaikka tässä kombinaatiossa on paljon vanhaa materiaalia, lopputulos on hyvin tuore näkökulma oman aikamme polttaviin ongelmiin. Kaari piirtyy rationaalisesta edistysuskosta pyhyyden ja humanismin kysymyksenasetteluihin.

Von Wright vertaa ihmiskunnan tilaa Dostojevskin Ivan Karamazoviin. Ivan Karamazov on peili, josta voimme katsella itseämme: sitä, millainen on äärinimilleen viedyn rationalismin tulos. Von Wright vertaa Ivan Karamazovia Euroopan valistushenkeen ja rationaaliseen optimisiniin ja ottaa vertailukohdaksi Neuvostoliiton romahduksen. Yritys luoda moderni ihminen edistyksellisessä yhteiskunnassa ja yritys luoda tulevaisuuden malli oli tuomittu epäonnistumaan. Markkinatalous ei kuitenkaan omassa yltiörationalismissaan voi tuoda ratkaisua, vaan se toistaa pääpiirteissään samoja pyrkimyksiä ja virheitä modernin ihmisen ja tulevaisuuden yhteiskunnan luomiseen, Von Wright kysyykin: 
"Jos Neuvostoliiton loppu muistuttaa Smerdjakovin itsemurhaa, millaisen kohtalon uskomme odottavan henkiin jäänyttä maailmanvaltaa, kun markkinavoimat on päästetty valloilleen vapaasti ja minkään niitä uhkaamatta?"

Von Wrightin mukaan olevaisuuden kolme valtaa ovat luonto, ihminen ja jumala. Pyrkimys eheään maailmankatsomukseen on yritys saattaa nämä elementit tasapainoon. Hänen mukaansa Dostojevskin tuotannossa näistä elementeistä hallitsee ihminen. Dostojevskin

Kellariloukon mies on niitä modernein ihminen, jolla on "tietoisuuden ongelma". Tietoisuus estää kyvyn moraaliin ja sankaruuteen. Tietoinen ihminen on kykenemätön hyvään tai pahaan. Hänessä ei ole koossa pitävää moraalista koheesiota, vaan tietoisuus pilkkoo hyvyyden ja pahuuden ainekset kuin vääjäämätön kemiallinen hajoamisprosessi.

Von Wright näkee Dostojevskin tuotannossa sosialismin ensisijaisesti uskonnollisena, ei taloudellisena eikä poliittisena kysymyksenä, kuten Verhovenski Riivaajissa toteaa:

"Kysymyksessä on uusi uskonto, joka on korvaava vanhan."

Kulttuurin muoto ja käsite voidaan von Wrightin mukaan myös nähdä koheesiovoimien kautta. Spenglerin ajatus kulttuurien alkukuvista ja kulttuurien läpikäymä pseudomorfoosi voidaan hahmottaa historiassa esiintyvinä "motiivien tihentyminä". Vaikkakin von Wright suhtautuu Spenglerin ajatteluun kriittisesti, hän haluaa nostaa siitä esiin uutta luovaa ajattelua. Tällä hän tarkoittaa Spenglerin syklistä historiannäkemystä lineaarisen ajattelun sijaan.

Von Wright vertailee mielenkiintoisella tavalla Spenglerin ja Tbyribeen näkemyksiä historiasta ja kulttuurista. Toynbeen erona Spengleriin verrattuna on hänen "tieteellinen" eli kausaalisuhteita korostava metodinsa. Von Wright suhtautuu molempiin kriittisesti, mutta haluaa samalla nostaa esiin heidän kysymystenasettelujensa hedelmällisyyden. Tämä on tietysti hyvin poikkeavaa kohtaamista ja kuuntelua, joka ei ole ollut tyypillistä

suomalaiselle keskustelukulttuurille. Eli kuten von Wright toteaa lopuksi, molempia voidaan syyttää siitä, että he kietovat tutkimuskohteensa filosofisiin utupilviin, mutta samanaikaisesti heitä voidaan kiittää siitä, että kun utu on hajotettu, on paljon arvokasta jäänyt jäljelle.

Myös Tolstoille uskonto oli se voima, joka tekee ihmiselle ylipäänsä mahdolliseksi elää' tietoisena kuolemasta. Kuitenkin von Wrightin analyysissä Tolstoista korostuvat tämän järjelliset pyrkimykset, jossa skeptisismin avulla koetetaan ratkaista elämän ja kuoleman arvoituksia. Von Wright näkee Tolstoin ennen muuta anarkistina, yhtenä historian suurimmista anarkisteista joka pohtii tahdon vapauden suhdetta välttämättömyyteen. Tolstoi asettaa hänen mukaansa vapauden ja välttämättömyyden mielenkiintoisella tavalla suhteeseen tietämättömyyden ja tiedon käsitteiden kanssa. Von Wright tuo esiin sen, ettei historiallinen välttämättömyys riipu vain siitä, mikä sitä on edeltänyt, vaan ainakin yhtä suuressa määrin siitä, mikä seuraa myöhemmin sen jälkeen. Tolstoille myös taiteen arvo näyttäytyi sen luoman uskonnollisen tunteen voimana. Myös "puhtaasti" esteettisissä kokemuksissa syvin tunne on luonteeltaan uskonnollista riippumatta siitä, onko tuon tunteen kokija itse ateisti. Tolstoin mukaan uskontoa ei voida perustaa tieteeseen, mutta tiede sen sijaan perustuu aina uskontoon. Tolstoi torjuu ajatuksen tieteestä maailmanhistoriallisena vakiona:

"Tiede on ollut ja tulee aina olemaan vain sellaisten ilmiöiden tutkimista, jotka uskonto valitsee arvo- ja tärkeysjärjestyksessä kaikkien niiden lukemattomien asioiden ja ilmiöiden joukosta, joita voidaan tutkia. Siksi tiede ei ole yksi ja jakamaton, vaan on olemassa yhtä monta tiedettä kuin on uskontojakin."

Teoksen viimeisessä esseessä Viimeisistä ajoista: ajatusleikki von Wright peilaa omaa aikaamme ja sen ongelmia sekä omaa pessimismiään maailman katastrofien uhkien edessä. Hän poimii ihmiskunnan suurista vitsauksista esiin autoilun ja massaturismin, jotka kuluttavat maapalloa enemmän kuin mitkään muut asiat ja joista luopuminen ei ole lainkaan todennäköistä. Myöskään työttömyyttä luovalle työn automatisoinnille hän ei näe loppua. Von Wright nostaa esiin mahdollisuuden työn uudenlaiseen jakamiseen työaikaa ja paikkaa jakamalla ja vähentämällä. Tätäkään kehitystä ei voi pitää kovin todennäköisenä ja helppona tienä, vaikka tietoinen elintason lasku olisikin ainoa mahdollisuus.

Von Wright ei kuitenkaan itse pidä näkemystään globaalista kehityksestä kaaosta kohti pessimismin ilmauksena. Vaikka pessimisminä voidaan pitää sitä, ettei jaksa uskoa kehityksen suunnitelmalliseen ja järkevään ohjaukseen. järjellä ei ole riittävää voimaa ihmisten keskinäisessä vuorovaikutuksessa. Kuitenkaan tulevaisuuden yllätykset eivät ole pelkästään tuskallisia. Von Wright toteaa, että kohtaaminen odottamattoman kanssa tarjoaa ensi sijassa kehotuksen uuteen ajatteluun ja uudelleen arvioimiseen. Tästä prosessista voi kasvaa esiin aivan uusia ja ennen kuvittelemattomia asioita. Von 
Wright toteaa pessimisminsä tarkoittavan lyhyttä perspektiiviä. Pidemmällä aikavälillä on mahdollista jopa oppia ennen näkemättömiä asioita:

"Sellainen, joka oivaltaa maapallon olosuhteiden muuttumisen välttämättömyyden - ilman, että hän sen takia omaksuu jonkinlaisen utopian muutosten laadusta ja niiden siunauksellisuudesta - hänen ei tarvitse etsiä lohtua "voimattomuuden optimismista" eikä vaipua ,toivottomuuden pessimismiin".

Hannele Koivunen 